\title{
Exclusion of Angiotensin I-Converting Enzyme as a Candidate Gene Involved In Exudative Inflammatory Resistance in F344/N Rats
}

\author{
Mehrnaz Jafarian-Tehrani ${ }^{1}$, Samuel Listwak ${ }^{1}$, Ruth M. Barrientos ${ }^{1}$, \\ Annie Michaud ${ }^{2}$, Pierre Corvol ${ }^{2}$, and Esther M. Sternberg ${ }^{1}$ \\ ${ }^{1}$ Section on Neuroendocrine Immunology and Behavior, National Institutes of \\ Health, Bethesda, Maryland, U.S.A. \\ ${ }^{2}$ Institut National de la Santé et de la Recherche Médicale Unité 36, Collège de \\ France, Paris, France.
}

Accepted February 8, 2000.

\begin{abstract}
Background: Inbred LEW/N and F344/N rats respectively, are susceptible and relatively resistant to a broad range of inflammatory/autoimmune diseases. We recently identified a quantitative trait locus (QTL) on chromosome 10 that protects the $\mathrm{F} 344 / \mathrm{N}$ rat from carrageenan-induced exudation in a dominant fashion. Angiotensin I-converting enzyme $(A C E)$ is one of the candidate genes located in this QTL region that plays an important role in inflammation.

Materials and Methods: RNA was extracted from both LEW/N and F344/N rat strains and used to produce full length cDNA by reverse transcription polymerase chain reaction (RT-PCR). Both strands of the PCR products were entirely sequenced to determine nucleotide differences between strains. ACE activity was measured using the synthetic substrate ${ }^{3} \mathrm{H}$-hippuryl-glycylglycine. ACE protein levels were determined by Western blot using a specific ACE antibody. ACE kinetic and inhibition studies were performed using specific substrates (Hip-His-Leu and Acetyl-Seryl-Aspartyl-Acetyl-Lysyl-Proline) and inhibitors (lisinopril, captopril and quinaprilat) for each $\mathrm{C}$ - and N-terminal active site. Finally, the doseeffects of lisinopril treatment on carrageenen-induced exudate volume and ACE activity was studied.
\end{abstract}

Results: In this study, we report for the first time a missense mutation in the coding region of ACE CDNA at 5' 1021 from $\mathrm{C}$ to $\mathrm{T}$, resulting in a Leu-341 to Phe substitution, close to the $\mathrm{N}$ domain active site in the $\mathrm{F} 344 / \mathrm{N}$ rats. Full characterization of soluble and tissue ACE in both LEW/N and F344/N rat strains showed that soluble ACE levels in serum and exudate were 1.5 fold higher in the $\mathrm{F} 344 / \mathrm{N}$ rats than those in LEW/N rats. In addition, the soluble ACE level was inversely correlated with the exudate volume. However, the specific ACE activity and its catalytic properties were identical in both strains. Furthermore, the chronic inhibition of serum and exudate ACE levels by lisinopril treatment did not affect the exudate volume in $\mathrm{F} 344 / \mathrm{N}$ rats, indicating that several factors besides ACE were involved in the control of carrageenan-induced exudation.

Conclusions: This report describes a complete molecular, biochemical, enzymatic and pharmacologic study of a missense mutation in the ACE cDNA in F344/N rats, that taken together, excludes $A C E$ as a candidate gene involved with resistance to carrageenan-induced exudation in F344/N rats.

\section{Introduction}

Inbred Lewis (LEW/N) and Fischer (F344/N) rats differ widely in their neuroendocrine and inflammatory responses to a variety of anti- genic and pro-inflammatory stimuli (1-5). LEW/N and F344/N rats respectively, are susceptible and relatively resistant to a broad range of inflammatory/autoimmune diseases. 
Recently, we performed a genome scan in an $(\mathrm{LEW} / \mathrm{N} \times \mathrm{F} 344 / \mathrm{N}) \mathrm{F} 2$ intercross using as a quantitative trait, exudate volume, which is one component of the innate inflammatory response to subcutaneously injected carrageenan (6). This trait is a sub-trait of more complex autoimmune diseases, such as arthritis. We identified a quantitative trait locus (QTL) on chromosome 10 that protects the $\mathrm{F} 344 / \mathrm{N}$ rat from exudation in a dominant fashion (6). This QTL has a peak likelihood of odds (LOD) score of 4.3 and covers an approximate $10 \mathrm{cM}$ interval on chromosome 10 (6). This locus is particularly interesting, since it is one of the many regions that has been linked to collagen- and oilinduced arthritis using (DA $\times$ F344/N) F2 and $(\mathrm{DA} \times$ LEW.1AV1) F2 intercrosses, respectively $(7,8)$. This finding supports the notion that this region of chromosome 10 contains genes that control the innate inflammatory component of more complex autoimmune inflammatory disease. Furthermore, this region of rat chromosome 10 is syntenic to a region on human chromosome 17 that links to a variety of human autoimmune/inflammatory diseases, including multiple sclerosis (9). These findings indicate that this region on rat chromosome 10 and its counterpart on human chromosome 17 contain important non-major histocompatibility candidate genes involved in a wide range of inflammatory diseases.

A potential candidate gene located within this QTL region on chromosome 10 for exudative inflammatory resistance phenotype is Angiotensin I-Converting Enzyme ( $A C E)$, which is known to play an important role in the innate phase of inflammation (6). Several pieces of evidence support the possibility that ACE could be a potential candidate gene involved with the inflammation trait, particularly in the control of plasma extravasation. ACE is a key enzyme of the renin-angiotensin system that regulates blood pressure, salt and fluid ho-

\footnotetext{
Address correspondence and reprint requests to: Esther M. Sternberg, M.D., Chief, Section on Neuroendocrine Immunology and Behavior, CNENIMH/NIH, Bldg. 10-Rm. 2D-46, 10 Center Dr., MSC 1284, Bethesda, MD 20892, U.S.A. Phone: 301-402-2773; Fax: 301-402-1561; E-mail: ems@codon.nih.gov

OR

Mehrnaz Jafarian-Tehrani, Ph.D.: Université René

Descartes, Faculté des Sciences Pharmaceutiques et Biologiques, Laboratoire de Pharmacologie (EA 2510), 4, av de l'Observatoire. 75270 Paris cedex 06, France. Fax:

33+1-43-26-46-97; Phone: 33-1-53-73-97-86;

E-mail: jafarian@pharmacie.univ-paris5.fr
}

meostasis and plays a role in inflammation (10). ACE converts inactive angiotensin-I to the vasoconstrictor angiotensin-II. In addition, ACE inactivates the vasodilator pro-inflammatory bradykinin and substance P peptides (11). Several studies with rodents have shown that acute ACE inhibition could: (i) cause plasma extravasation mediated by bradykinin and substance $P(12)$, and (ii) potentiate rat paw edema induced by bradykinin (13) or carrageenan (14). In humans, it is also well known that therapy with ACE inhibitors can be associated with cough and angioneurotic edema (15). Hence, an abnormality in ACE structure could affect pro-inflammatory peptide degradation and, therefore, potentiate or suppress the inflammatory reaction.

ACE is a zinc-dependent ectoenzyme with two somatic and germinal isoforms derived from a single gene with two alternate promoters (16). Somatic ACE is expressed in endothelial, epithelial and neuroepithelial cells; whereas germinal ACE is expressed in testis $(10,17)$. The somatic membraneous ACE is a 170 kDa glycoprotein containing two homologous catalytic active sites at the $\mathrm{C}$ - and $\mathrm{N}$ terminal regions of the enzyme, called $\mathrm{N}$ - and C-domain active sites (18-20). Both active sites are functional catalytically and have their own substrate and inhibitor specificity (21-26). Germinal membraneous ACE is a 100 kDa glycoprotein containing only the $\mathrm{C}$-domain active site $(27,28)$. Soluble somatic ACE usually results from the solubilization of the extracellular portion of membraneous ACE $(29,30)$, from pulmonary endothelial and kidney epithelial cells by a secretase (31) and has the same catalytic properties as membraneous ACE (32). This soluble enzyme is found in body fluids such as plasma, cerebrospinal fluid, lung edema and lymph (17).

The best-defined physiological role of ACE, the control of blood pressure, is mediated by somatic membraneous ACE (33). Although the role of soluble ACE is not very well understood, its level is altered in several diseases such as rheumatoid arthritis (34), systemic lupus erythematosus (34), Alzheimer's (35), scleroderma (36) and sarcoidosis (37). This is probably a result of inflammation, since macrophages $(38,39)$, T lymphocytes $(40)$, endothelial cells (41) and discrete areas of the brain, such as choroid plexus $(42,43)$, express large amounts of this enzyme.

In this report, we studied $A C E$ as a candi- 
date gene for resistance to exudation in F344/N, compared with LEW/N rats. We chose the $A C E$ gene because of both its importance in inflammation and its presence in a region of chromosome 10 that is linked to resistance to inflammatory exudation. In this report, we identified a missense mutation in the coding region of $\mathrm{F} 344 / \mathrm{N} A C E$ cDNA, close to the Ndomain active site. This mutation is associated with a high soluble ACE level and very low exudate volume in $\mathrm{F} 344 / \mathrm{N}$ rats, although the mutation does not affect the apparent ACE-specific activity and its kinetic parameters.

\section{Materials and Methods}

Animals and Treatments

Inbred, pathogen-free F344/N and LEW/N rats were obtained from Harlan Sprague Dawley (Indianapolis, IN) and maintained according to the National Institutes of Health (NIH) Guide for Use of Laboratory Animals. At 9-10 weeks of age, male rats were subcutaneously injected with $4 \mathrm{ml}$ of $2 \%$ carrageenan lambda (Sigma, St. Louis, MO) or $0.9 \%$ saline ( $n=8$ per group), as previously described (44), with modifications to reflect the chronic phase of inflammation (5). Lisinopril (Sigma) or saline treatment $(0.4 \mathrm{ml})$ was performed intraperitoneally (i.p.) $3 \mathrm{hr}$ before carrageenan injection. Dose-effect of lisinopril treatment on carrageenan-induced exudate volume and ACE activity was studied at three different doses of $0.5,3$ and $10 \mathrm{mg} / \mathrm{kg}$ of body weight (bw) twice a day, for 10 days. The heparinized plasma from trunk blood, exudate and organs were collected after 10 days carrageenan post-injection, and frozen at $-70^{\circ} \mathrm{C}$ until use.

\section{Sequence Analysis}

RNA was extracted from lung by using RNeasy Maxi Kit (Qiagen Inc., Santa Clarita, CA), according to manufacturer's instructions. Reverse transcription polymerase chain reaction (RTPCR) was performed using GeneAmp RNA PCR Core Kit (Perkin Elmer Corp., Branchburg, NJ), Perkin-Elmer GeneAmp PCR system 9600, and $A C E$-specific primers. One $\mu \mathrm{g}$ of the total RNA from each rat strain was reversetranscribed into cDNA. The following sets of primers, based on the Wistar-Kyoto (WKY) rat
$A C E$ cDNA sequence (45), were then used to amplify the entire coding region of cDNA from both LEW/N and F344/N rats. Primer pairs used, sequence $\left(5^{\prime}\right.$ to $\left.3^{\prime}\right)$ locations and product sizes were as follows. (1) CGCCGCACCG CGCGCACCGCGCCAT - (836) GCGGCGGTG CAGTGCGCGACGGA, 836 bp; (263) CATCACGGAGGAGAATGCG - (1529) TCG AAGA TACCACCAGTCGTAG, 1267 bp; (1414) CCCTAGAGAAAATTGCCTTCTTG - (2659) CCATCCAGGTTGATGTACTCAG， 1246 bp; (2480) CAAGCTCAACGGCTACTCTGATG(3427) AAGTACCTGATGTATGGCACATTCG, 948 bp; (3395) CGTTCCTGCGAATGTGCCATAC - (3974) AGGGTCACCTCAGGAGTGTCTGAGC, 580 bp. PCR conditions were 1 cycle at $95^{\circ} \mathrm{C}$ for $5 \mathrm{~min} ; 45$ cycles of $95^{\circ} \mathrm{C}, 1$ $\min / 55^{\circ} \mathrm{C}, 1 \mathrm{~min} / 72^{\circ} \mathrm{C}, 1 \mathrm{~min}$ and one final cycle of $72^{\circ} \mathrm{C}$ for $7 \mathrm{~min}$. Appropriately sized PCR products were agarose gel-purified using a Gene Clean Spin Kit (BIO 101, Vista, CA). Both strands were then sequenced using the BigDye Terminator Cycle sequencing kit (PE Biosystems, Foster City, CA), according to the supplied protocol and analyzed on a ABI 377 automated sequencer (PE Biosystems, Foster City, CA). Sequence alignments and comaprisons were performed using the MacVector computer software package (Oxford Molecular Ltd., Oxford, UK). To confirm that the differences in cDNA sequence between the LEW/N and F344/N strains obtained were not artifactual, total RNA was prepared from a separate set of LEW/N and F344/N rats and the regions containing these differences resequenced.

\section{GenBank Accession Numbers}

WKY $A C E$ cDNA U03734; F344/N ACE cDNA AF201331; LEW/N ACE cDNA AF201332.

\section{Tissue ACE Preparation}

Homogenized tissues were prepared as previously described (33). Briefly, organs were pre-cut, homogenized in $4 \mathrm{ml} / \mathrm{g}$ tissue of cold $\mathrm{N}$-2-hydroxyethylpiperazine- $\mathrm{N}$-2-ethanesufonic acid (HEPES) Buffer ( $50 \mathrm{mM}, \mathrm{pH}=7.4)$, complemented with $25 \mu \mathrm{M} \mathrm{Zn} \mathrm{SO}$, $8 \mathrm{mM}$ (3-[(3cholamidopropyl)dimethylammonia]-1-propanesulfonate (CHAPS) and protease inhibitor cocktail-EDTA free (Boehringer Mannheim, Germany), and clarified at $4^{\circ} \mathrm{C}$ at $10.000 \mathrm{~g}$ for $15 \mathrm{~min}$. 


\section{Western Blots Analysis}

Purified ACE from human kidney (Chemicon, Temecula, CA) was used as a standard. Plasma and homogenized tissues from LEW/N and F344/N rats were separated by SDS-PAGE on a NuPAGE tris-actetate 3-8\% gel (Novex, San Diego, CA) under denaturing and reducing conditions. Multimark multicolored standard (Novex, San Diego, CA) was used to determine protein molecular weights in the samples. The separated proteins were transfered to polyvinylidene difluoride (PVDF) membranes (Amersham Pharmacia Biotech., Piscataway, NJ). The ACE protein was detected by a rabbit polyclonal anti-mouse ACE antibody, kindly provided by Dr. Kenneth E. Bernstein (Emory University, Atlanta, GA), as previously described $(33,46)$, with minor modifications. The secondary antibody, a donkey anti-rabbit immunoglobulin -Ghorseradish peroxide (IgGHRP), and an Enhanced Chemiluminescent Protein Detection Kit (ECL + Plus) were purchased from Amersham Pharmacia Biotech. Finally, the blots were scanned by the Molecular Dynamics Storm 860 (Molecular Dynamics, Sunnyvale, $\mathrm{CA})$ in blue fluorescence/chemifluorescence mode and the intensity of the bands was measured using ImageQuant image analysis Software (Molecular Dynamics).

\section{ACE Assays}

As previously described (33), ACE activity against the synthetic substrate ${ }^{3} \mathrm{H}$-hippurylglycylglycine $\left({ }^{3} \mathrm{H}-\mathrm{HGG}\right)$ was directly measured in the unpurified individual samples of plasma, exudate and homogenized tissues using ACE ${ }^{3} \mathrm{H}$ Direct Radioenzymatic Assay (REA) kit (ALPCO Ltd., Windham, NH) according to the manufacturer's instructions. One unit of ACE activity is defined as the amount of enzyme required to release one $\mu$ mole of hippuric acid per minute per liter. The specificity of the assay was tested by incubation of the samples with $0.3 \mu \mathrm{M}$ of an ACE inhibitor lisinopril (Sigma, St. Louis, MO), which completely abolished the ACE activity. Total proteins were measured in samples by using bicinchoninic acid (BCA) Protein Assay Kit (Pierce, Rockford, IL). Data were reported as enzymatic activity per unit (U) or corrected by the total protein $(\mathrm{nmol} / \mathrm{min} / \mathrm{mg}$ protein). Statistical analyses were performed using JMP software (SAS Institute Inc., Cary, NC).

\section{ACE Kinetic Studies}

Hip-His-Leu (HHL) (Bachem, Switzerland) and Acetyl-Seryl-Aspartyl-Acetyl-Lysyl-Proline (AcSDAcKP) (synthetized at Neosystem SA, Strasbourg, France) were used as relatively Cand $\mathrm{N}$-domain-specific substrates, respectively. Kinetic constants for the hydrolysis of HHL were determined as previously described (47), with a minor modification. HHL hydrolysis reactions were performed on samples with similar ACE activity and under initial velocity with less than $10 \%$ substrate hydolysis. Dilution of plasma and lung extract was adjusted to measure similar ACE activity (around 1-3 $\mathrm{nmol} / \mathrm{ml} / \mathrm{min})$. Samples and standard HHL from 0.2 to $5 \mathrm{mM}$ were incubated in $100 \mathrm{mM}$ potassium phosphate, $\mathrm{pH}=8.3,300 \mathrm{mM} \mathrm{NaCl}$, at $37^{\circ} \mathrm{C}$ for $1 \mathrm{hr}$ in a total volume of $250 \mu \mathrm{l}$. The hydrolysis was stopped by the addition of $50 \mu \mathrm{l}$ of $12 \% \mathrm{H}_{3} \mathrm{PO}_{4}$. The generated hippuric acid (HA) and HHL were resolved and quantified by reverse-phase HPLC on a $10 \mu \mathrm{m}$ Nucleosil C18 column (Waters, Milford, MA) with 19\% $\mathrm{CH}_{3} \mathrm{CN}$ in $10 \mathrm{mM} \mathrm{KH} \mathrm{PO}_{4},(\mathrm{pH}=3)$, at a flow rate of $1 \mathrm{ml} / \mathrm{min}$. HA (retention time $=7 \mathrm{~min}$ ) and HHL (retention time $=11 \mathrm{~min}$ ) were detected using a monitor set at $228 \mathrm{~nm}$.

Kinetic constants for the hydrolysis of AcSDAcKP were determined, based on a protocol from our laboratory (M. Azizi, C. Massien, A. Michaud and P. Corvol, INSERM U36, Paris, France). The hydrolysis reactions were performed on samples with similar ACE activity and under initial velocity with less than $10 \%$ substrate hydolysis. Dilution of plasma and lung extract was adjusted to measure similar ACE activity (10 pmol/ml/min). Samples and standard AcSDAcKP from 0.01 to $2 \mathrm{mM}$ were incubated in $50 \mu \mathrm{M}$ HEPES, $\mathrm{pH}=7,50 \mathrm{mM}$ $\mathrm{NaCl}$, at $37^{\circ} \mathrm{C}$ for $1 \mathrm{hr}$ in a total volume of $250 \mu \mathrm{l}$. The hydrolysis was stopped by the addition of $50 \mu \mathrm{l}$ of $0.5 \%$ trifluoroacetic acid (TFA). The generated Acetyl-Lysyl-Proline (AcKP) and AcSDAcKP were resolved and quantified by reverse-phase HPLC on a $5 \mu \mathrm{m}$ Puresil C18 column (Waters, Milford, MA) with a gradient of increasing concentrations of $\mathrm{CH}_{3} \mathrm{CN}$ in $\mathrm{H}_{2} \mathrm{O} / 0.1 \%$ TFA from $1 \%$ to $25 \%$ in $10 \mathrm{~min}$, and to $50 \%$ in $5 \mathrm{~min}$, at a flow rate of $1 \mathrm{ml} / \mathrm{min}$. AcKP (retention time $=11 \mathrm{~min}$ ) and AcSDAcKP (retention time $=13.5 \mathrm{~min}$ ) were detected using a monitor set at $200 \mathrm{~nm}$. Kinetic parameters $\left(K_{m}\right.$ and $\left.V_{\max }\right)$ for C- and N-domainspecific substrates were calculated from 
Michaelis-Menten plots using ENZFITTER software (BIOSOFT, Cambridge, UK).

\section{ACE Inhibition Studies}

The inhibition parameters $\left(I C_{50}\right)$ for ACE inhibitors lisinopril (donated by Merck Sharp and Dohme, Paris, France), captopril (a gift from Bristol-Myers Squibb, Princeton, NJ), quinaprilat (a gift from Parke-Davis, Ann Arbor, MI) were determined as previously described (47), with minor modification. Diluted plasma and lung extract, with a similar ACE activity of 0.2-0.4 nmol of generated hippuric acid $/ \mathrm{ml} / \mathrm{min}$, were first pre-incubated at $37^{\circ} \mathrm{C}$ for $1 \mathrm{hr}$ with various doses of ACE inhibitors, lisinopril from 0.01 to $0.75 \mathrm{nM}$, captopril from 0.1 to $7.5 \mathrm{nM}$, and quinaprilat from 0.05 to $2.5 \mathrm{nM}$. Hydrolysis was initiated by the addition of $0.5 \mathrm{mM}$ HHL and $I C_{50}$ determined using PRISM software (Graph Pad Software, Inc., San Diego, CA).

\section{Results}

ACE Activity In the Plasma and Exudate of Carrageenan-treated F344/N Rats

To investigate the role of ACE gene candidate in the resistance to carrageenan-induced exudation in F344/N rats, we measured the ACE activity in both the plasma and exudate of LEW/N and F344/N rats (Table 1). The levels of
ACE activity in the plasma and exudate were found to be 1.5- to 2 -fold in F344/N, compared with LEW/N rats (Table 1). Interestingly, the ACE activity (U) in plasma decreased to $25-30 \%$ of basal level in both strains, in parallel with a decrease in total protein in the plasma after 10 days carrageenan-induced exudation (Table 1). Moreover, the levels of exudate ACE activity and exudate volume (Table 1) were inversely correlated $\left(\mathrm{r}^{2}=0.5581, p=\right.$ 0.0009) in both strains. Outbred Harlan Sprague-Dawley rats, often used in carrageenan-induced inflammation studies (48), showed similar ACE activity and moderate exudate volume, compared with LEW/N rats (data not shown).

\section{Identification of a Missense Mutation In the ACE cDNA Sequence of F344/N Rats}

The PCR products of the full length of $A C E$ cDNA were performed using five sets of primer pairs. No splice variant was found in either LEW/N or F344/N rats (not shown). Sequence analysis of the full-length ACE cDNA from both strains showed three nucleotide differences in the F344/N rats (Fig. 1). This resulted in a $\mathrm{C}$ to $\mathrm{T}$ change at 5'1021 (Fig. 1), a $\mathrm{G}$ to $\mathrm{T}$ change at $5^{\prime} 1812$, and a $T$ to $C$ change at $5^{\prime}$ 2513 (data not shown). Based on the sequence of $A C E$ cDNA in WKY rats (45), a similar open reading frame was found in both $\mathrm{LEW} / \mathrm{N}$ and $\mathrm{F} 344 / \mathrm{N}$ rats. Therefore, a $\mathrm{C}$ to $\mathrm{T}$ change at

Table 1. Angiotension I-converting enzyme (ACE) activity in the plasma and exudate of inbred LEW/N and $\mathbf{F 3 4 4 / N}$ rats after 10 days carrageenan-induced exudation.

\begin{tabular}{|c|c|c|c|c|}
\hline \multirow{2}{*}{$\begin{array}{l}\text { Inbred Strains } \\
\text { Treatments }\end{array}$} & \multicolumn{2}{|c|}{$\mathbf{L E W} / \mathbf{N}$} & \multicolumn{2}{|c|}{ F344/N } \\
\hline & Saline & Carrageenan & Saline & Carrageenan \\
\hline Total Protein In Plasma (mg/ml) & $55.7 \pm 7.7$ & $43.5 \pm 8.4^{\mathrm{a}}$ & $62.8 \pm 5.0$ & $46.8 \pm 3.0^{\mathrm{b}}$ \\
\hline ACE Activity In Plasma (U) & $55.1 \pm 1.8$ & $36.1 \pm 1.8^{\mathrm{c}}$ & $87.3 \pm 3.8^{\mathrm{d}}$ & $61.8 \pm 4.0^{\mathrm{e}, \mathrm{f}}$ \\
\hline ACE Activity In Plasma (nmol/min/mg) & $1.00 \pm 0.12$ & $0.85 \pm 0.12$ & $1.39 \pm 0.08^{\mathrm{g}}$ & $1.32 \pm 0.09^{\mathrm{h}}$ \\
\hline Total Protein In Exudate (mg/ml) & NA & $25.9 \pm 1.7$ & NA & $22.7 \pm 2.3$ \\
\hline ACE Activity In Exudate (U) & NA & $16.0 \pm 1.5$ & NA & $27.8 \pm 2.3^{i}$ \\
\hline ACE Activity In Exudate (nmol/min/mg) & NA & $0.62 \pm 0.08$ & NA & $1.22 \pm 0.10^{\mathrm{j}}$ \\
\hline Exudate Volume (ml) & 0 & $12.5 \pm 6.5$ & 0 & $0.68 \pm 0.50^{\mathrm{k}}$ \\
\hline \multicolumn{5}{|c|}{ 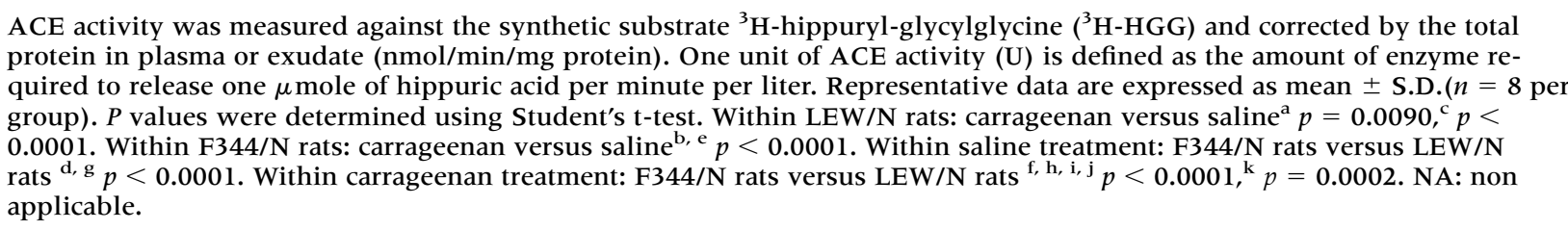 } \\
\hline
\end{tabular}


LEW/N
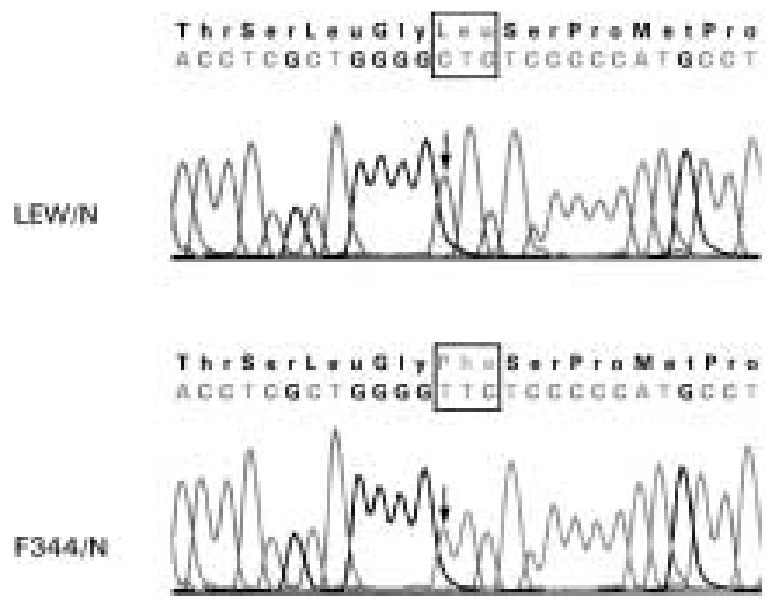

Fig. 1. Representative partial sequence 5' 1009-1035 of ACE CDNA from lung of LEW/N and $\mathrm{F} 344 / \mathrm{N}$ rats by using 5'263-1529 primer pairs. The polymerase chain reaction (PCR) products were sequenced. The missense mutation is indicated by an arrow at 5'1021 from $\mathrm{C}$ in $\mathrm{LEW} / \mathrm{N}$ rat to $\mathrm{T}$ in $\mathrm{F} 344 / \mathrm{N}$ rat. The corresponding codon and the deduced amino acid are shown in the box.
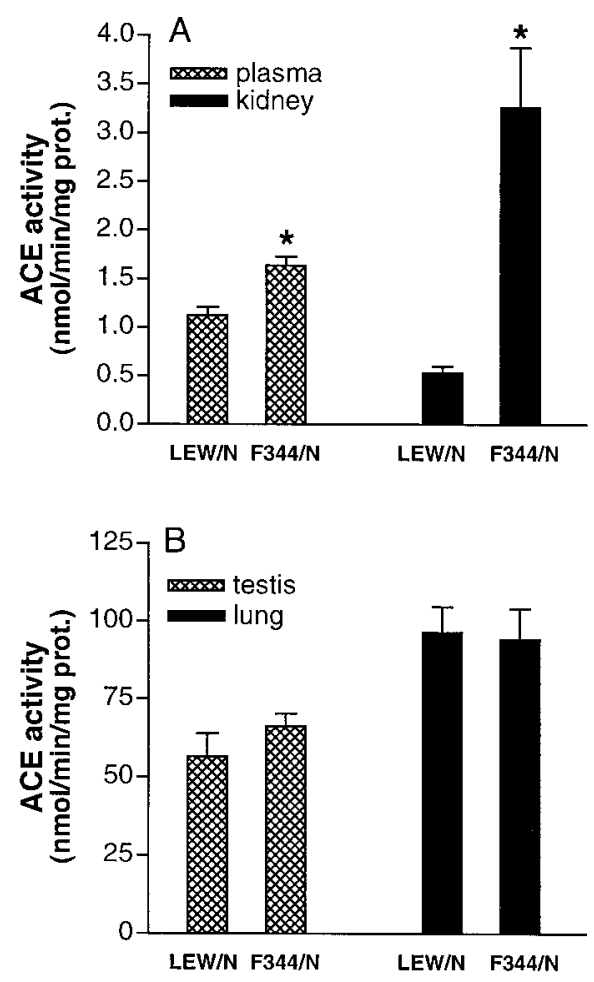

Fig. 2. Pattern of angiotensin I-converting enzyme (ACE) activity. Activity in plasma (A) and homogenized tissues such as kidney (A), lung and testis (B), liver and spleen (C), brain and pituitary (D) from naive LEW/N and F344/N rats. ACE activity was measured against the synthetic substrate ${ }^{3} \mathrm{H}$-hippuryl-glycylglycine $\left({ }^{3} \mathrm{H}-\mathrm{HGG}\right)$ in $10 \mu \mathrm{l}$ of
5'1021 was the only one to result in an amino acid substitution, from a hydrophobic amino acid Leu-34l in the LEW/N rats to a more bulky hydrophobic amino acid Phe-341 in the F344/N rat (Fig. 1). This occurred 53 amino acids up-stream of the $\mathrm{N}$-domain active site of ACE. Interestingly, the missense mutation found in the F344/N rats abolished the consensus sequence (GPuGCPyC) (49) of BANII restriction enzyme. Therefore, the PCR products containing this mutation were resistant to the BANII enzyme digestion (not shown). Moreover, outbred Harlan Sprague-Dawley rats did not have this mutation and had the same nucleotide at position 5'1021 of the ACE cDNA as that of LEW/N rat (data not shown).

Determination of Soluble ACE and Pattern of Tissue ACE Activity In Naive LEW/N and F344/N Rats

To investigate whether or not this mutation had an influence on ACE activity in F344/N rats, we measured soluble and tissue ACE ac-
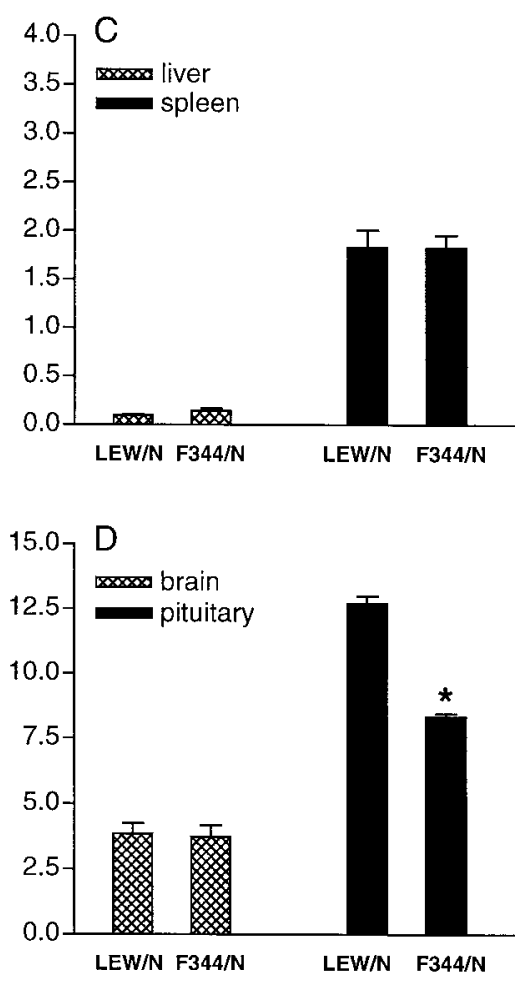

plasma or diluted homogenized tissues (diluted 1:20 for lung and testis, 1:2 for other samples). Values of ACE activity were corrected by the total amount of protein (nmol/min/mg protein). Representative data are expressed as mean \pm SD $(n=8)$. $*=p<0.0001$. 
tivity in both LEW/N and F344/N rats (Fig. 2). Testicular ACE activity was used as a control, since this ACE isoform only contained the Cdomain active site and, therefore, did not possess the missense mutation found close to $\mathrm{N}$ domain active site. As shown in Figure 2, the level of ACE activity in $\mathrm{F} 344 / \mathrm{N}$, compared with LEW/N rats, was 1.5 - and 5-fold higher in the plasma and kidney, respectively (Fig. 2A), 1.5-fold lower in the pituitary (Fig. 2D). There was no significant difference between ACE activity in the two strains in the lung, testis (Fig. 2B), spleen, liver (Fig. 2C) and brain (Fig. 2D). The ACE activity in the plasma, kidney and pituitary from Sprague-Dawley rats was similar to those of sex- and age-matched LEW/N rats (data not shown). These data suggest a tissuespecific difference of ACE activity in F344/N rats. The level of ACE activity in different tissues ranged from high to low, with lung $>$ testis $>$ pituitary $>$ brain $>$ spleen $>$ plasma $>$ kidney (except in F344/N rats) > liver (Fig. 2). To determine whether the high renal ACE activity in the $\mathrm{F} 344 / \mathrm{N}$ rats was due to a difference in the soluble or membranous form of ACE, we measured ACE activity in the cytosol and membrane preparations from kidneys, compared with those from lungs. In both tissues, $98 \%$ of the ACE activity was membranous and the 5-fold increase in renal ACE activity in the F344/N rats (Fig. 2A) was due to a high level of membranous ACE activity (data not shown). It suggests that the strain difference in renal ACE activity likely was not related to a difference in the ACE solubilization.

\section{Quantification of Soluble and Tissue ACE by Western Blots}

To determine the electrophoretic mobility of ACE and quantify the amount of soluble and tissue ACE in naive LEW/N and F344/N rats, total proteins from plasma (Fig. 3A), homogenized lung (Fig. 3A,B), kidney and testis (Fig. 3B), spleen, brain and pituitary (not shown) were separated by SDS-PAGE. The molecular weights of soluble, somatic and germinal ACE were 170,170 and $110 \mathrm{kDa}$, respectively, and there was no difference in the electrophoretic mobility of ACE obtained from the two strains of rats (Fig. 3A,B). The amount of ACE protein was identical in homogenized lung from both strains, as well as in testis (Fig. 3B,C). In contrast, the amount of ACE protein in homogenized kidney was 5-fold higher
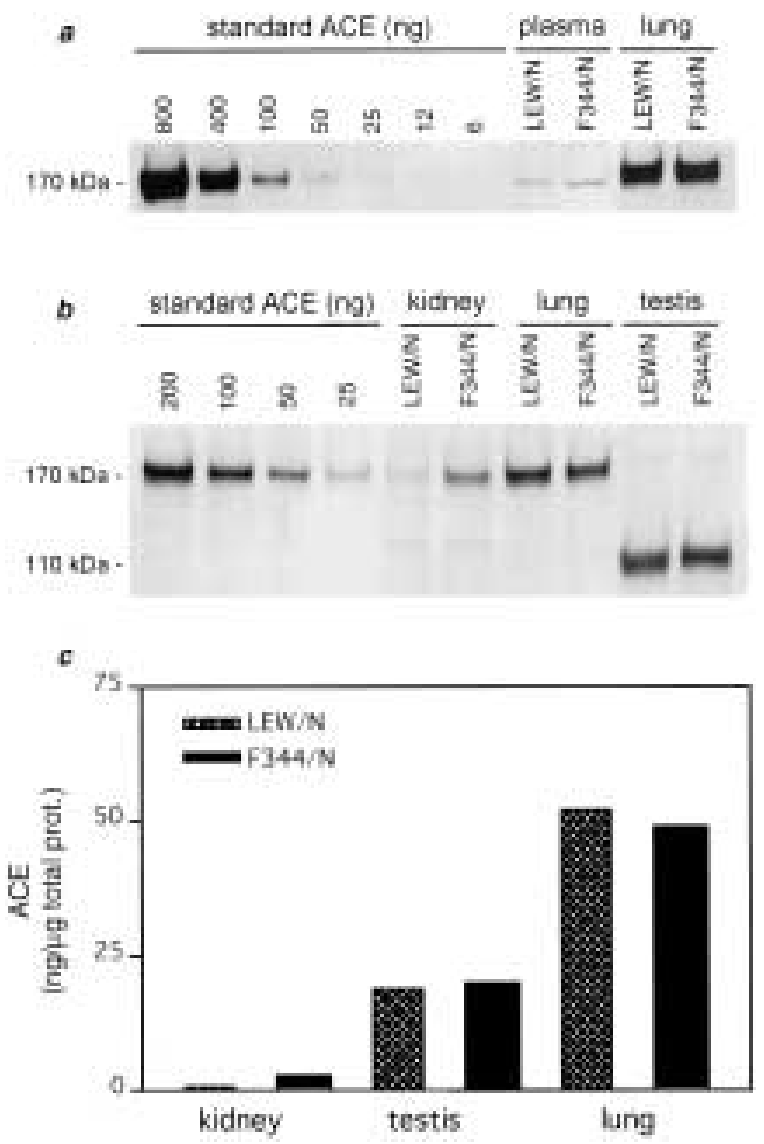

Fig. 3. Representative Western blots of angiotensin I-converting enzyme (ACE) protein detection. Western blots shown in the plasma (A), homogenized lung (A,B), kidney (B) and testis (B) from naive LEW/N and F344/N rats. Purified human ACE, used as a standard, and various amounts of total protein from plasma and homogenized tissues $(20 \mu \mathrm{g}$ for plasma and kidney, $5 \mu \mathrm{g}$ for testis, 2 to $3 \mu \mathrm{g}$ for lung) were run by SDSPAGE on a NuPAGE tris-acetate $3-8 \%$ gel. Proteins were transferred to the PVDF membrane and incubated over night at $4^{\circ} \mathrm{C}$ in the blocking buffer with the rabbit polyclonal anti-ACE antibody (1:4000). The detection was performed using an anti-rabbit (IgG-HRP) (1:10000) and an enhanced chemiluminescent plus $(E C L+)$ detection system. Blot was scanned in blue chemifluorescence mode (100 $\mu$ pixel size, PMT 1000 V) by the Storm 860. (C) Representative histogram of ACE quantification in homogenized tissues. The ACE bands were quantified using ImageQuant software. The quantification was performed using the linear portion of the standard curve made by serial dilution of pure ACE. Data are expressed as ng of ACE per $\mu \mathrm{g}$ of total protein.

in F344/N, compared with LEW/N rats (Fig. $3 \mathrm{~B}, \mathrm{C})$. The ACE level in plasma was also found to be slightly higher in $\mathrm{F} 344 / \mathrm{N}$ rats (Fig. 3A). Comparing the two rat strains, there was no difference in the amount of ACE in the 
brain and spleen, in contrast to a slightly low ACE (1.5-fold) level in the pituitary from F344/N rats (data not shown). Taken together, the ACE activity (Fig. 2) and Western blots ACE protein concentrations (Fig. 3) were parallel and, thus, indicated that there was no apparent difference in the specific activity of ACE, when corrected by the amount of ACE protein, between LEW/N and F344/N rats.

\section{Determination of Soluble and Tissue ACE Kinetic} $\left(K_{m}, V_{\max }\right)$ and Inhibition $\left(\mathrm{IC}_{50}\right)$ Parameters Using $C$ - and N-domain-specific Substrates and Inhibitors

To evaluate if the mutated form of ACE could affect the catalytic properties of the enzyme, specific substrates for both the $\mathrm{N}$ - and $\mathrm{C}$ domain active sites, as well as specific inhibitors for each site were used. HHL and AcSDAcKP were used as the specific substrates for $\mathrm{C}$ - and $\mathrm{N}$-domain active sites, respectively. $\mathrm{Ki}$ netic studies for both substrates were performed on plasma and homogenized lung and showed no significant differences in $K_{m}$ and $V_{\text {max }}$ in LEW/N and F344/N rats (Table 2). Furthermore, the ACE inhibitors lisinopril, captopril and quinaprilat were used to determine the $I C_{50}$ of the enzyme in plasma (Fig. $4 \mathrm{~A}$ ) and in homogenized lung (Fig. 4B) from both strains. The $I C_{50}$ values did not differ significantly between the two strains. In fact, in plasma, the $I C_{50}$ values for lisinopril, quinaprilat and captopril were 0.011 to $0.019 \mathrm{nM}, 0.033$ to $0.036 \mathrm{nM}$, and 7.89 to $14.78 \mathrm{nM}$, respectively. Moreover, in homogenized lung, the $I C_{50}$ values for lisinopril, quinaprilat and captopril were 0.009 to $0.018 \mathrm{nM}, 0.21$ to $0.27 \mathrm{nM}$, and 2.56 to $2.94 \mathrm{nM}$, respectively.
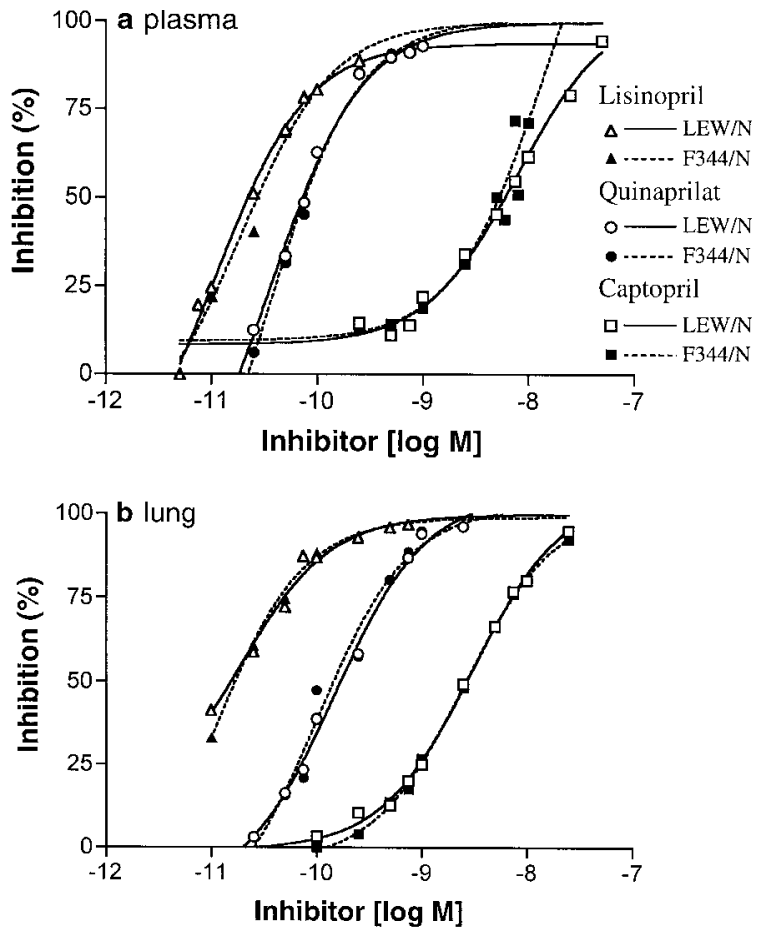

Fig. 4. Angiotensin I-converting enzyme (ACE) inhibition parameter $\mathrm{IC}_{50}$ determination. $I C_{50}$ determination in plasma (A) and homogenized lung (B) from naive LEW/N and F344/N rats using the C-domain substrate Hip-His-Leu (HHL) and different ACE inhibitors: lisinopril, quinaprilat and captopril. Pooled samples $(n=8)$ were used in these experiments. See "Materials and Methods" for more details.

\section{Lisinopril Dose Response On Soluble ACE Activity and Exudate Volume In Carrageenan-injected F344/N Rats}

To test the hypothesis of how lisinopril could reverse the amount of exudate volume, the

Table 2. ACE kinetic constants $\left(K_{m}\right.$ and $\left.V_{\text {max }}\right)$ determination in plasma and homogenized lung using specific $\mathrm{C}$ - and $\mathrm{N}$-domain substrates.

\begin{tabular}{|c|c|c|c|c|c|}
\hline & & C-dom & ubstrate (HHL) & N-domain & strate (AcSDAcKP) \\
\hline & & $K_{m}(\mathbf{m M})$ & $V_{\max }(\mathrm{nmol} / \mathrm{ml} / \mathrm{min})$ & $K_{m}(\mathbf{m M})$ & $V_{\max }(\mathrm{nmol} / \mathrm{ml} / \mathrm{min})$ \\
\hline Plasma & LEW/N & $2.25 \pm 0.07$ & $3.63 \pm 0.06$ & $2.12 \pm 0.82$ & $0.14 \pm 0.03$ \\
\hline & F344/N & $2.04 \pm 0.11$ & $3.41 \pm 0.09$ & $2.47 \pm 0.88$ & $0.21 \pm 0.04$ \\
\hline Lung & LEW/N & $1.32 \pm 0.13$ & $5.09 \pm 0.21$ & $7.36 \pm 1.96$ & $0.63 \pm 0.14$ \\
\hline & F344/N & $1.41 \pm 0.13$ & $5.04 \pm 0.20$ & $5.65 \pm 1.94$ & $0.33 \pm 0.09$ \\
\hline
\end{tabular}

Each $K_{m}$ and $V_{\max }$ value \pm S.E. was computed by the ENZFITTER program from iteration on 24 individual points. Pooled samples $(n=8)$ were used in these experiments. See "Materials and Methods" for more details. 

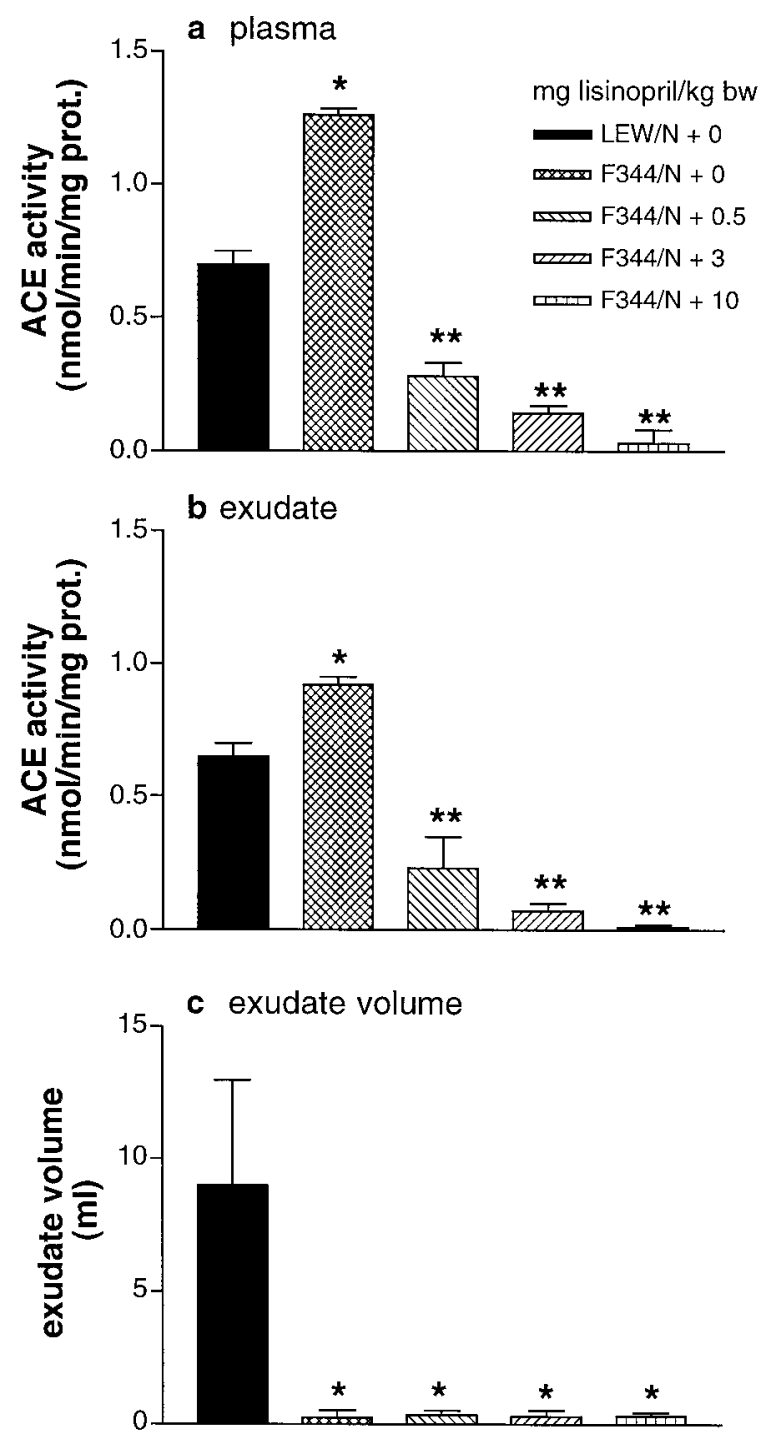

Fig. 5. Lisinopril dose-effect on angiotensin I-converting enzyme (ACE) activity. Activity in plasma (A), exudate (B), and exudate volume (C) after 10 days carrageenan-induced inflammation in $\mathrm{F} 344 / \mathrm{N}$ rats. LEW/N rats were used as a control of exudation. Three doses of $0.5,3$, and $10 \mathrm{mg} / \mathrm{kg}$ body weight lisinopril or saline treatment (i.p.) were performed $3 \mathrm{hr}$ before carrageenan injection and continued twice a day for 10 days. ACE activity was measured against the synthetic substrate ${ }^{3} \mathrm{H}$-hippuryl-glycylglycine $\left({ }^{3} \mathrm{H}-\mathrm{HGG}\right)$ and corrected by the total protein (nmol/min/mg protein). Data are expressed as mean $\pm \mathrm{SD}(n=3-5$ per group $) .{ }^{*}=p<$ 0.0001 saline- or lisinopril-treated $\mathrm{F} 344 / \mathrm{N}$ versus saline-treated LEW/N rats. ${ }^{* *}=p<0.0001$ lisinopriltreated F344/N versus saline-treated $\mathrm{F} 344 / \mathrm{N}$ rats.

carrageenan-injected F344/N rats were treated with different doses of the ACE inhibitor lisinopril. As shown in Figure 5, lisinopril inhibited plasma (Fig. 5A) and exudate (Fig. 5B) ACE activities in a dose- dependent fashion. In contrast, no difference was found in the exudate volume between saline- and lisinopril-treated F344/N rats (Fig. 5C).

\section{Discussion}

In this study, we report for the first time a missense mutation, a $\mathrm{C}$ to $\mathrm{T}$ change at 5'1021, in the coding region of $A C E$ CDNA in the F344/N rats associated with high soluble ACE levels. Full biochemical, enzymatic and pharmacologic characterization of ACE reveals that although this mutation results in an important amino acid substitution, Leu-341 to Phe, near the $\mathrm{N}$-domain active site of the enzyme, it is not associated with alterations in specific activity or catalytic properties of the ACE. Furthermore, although the gene is located within a QTL on chromosome 10 that links to resistance to exudative inflammation, treatment with an ACE inhibitor does not affect this phenotype in the resistant F344/N rats. Taken together, these findings provide strong evidence against ACE as the sole candidate gene involved with protection from exudative inflammation in F344/N rats.

The entire sequence of rat $A C E$ gene is not known. However, based on the exon-intron boundaries in the human $A C E$ gene (16) and the high homology of sequence between rat and human $A C E$ CDNA $(18,45)$, a $C$ to $T$ change at $5^{\prime} 1021$ is located in the exon 7 . It is upstream of the exon 8 coding for the $\mathrm{N}$-domain active site. Interestingly, in other inbred rat strains, such as Wistar-Kyoto (WKY) and stroke-prone spontaneously hyertensive (SHRSP) rats, the Leu at position 341 has been conserved (45). This Leu appears to be conserved in the human sequence as well (18). The three dimensional structure of ACE has not yet been elucidated. However, a Leu to Phe substitution could result in changes in protein folding and activity, as previously shown in chloramphenicol acetyltransferase (50).

Catalytic properties of the $\mathrm{C}$ - and $\mathrm{N}$ domain active sites have been studied in human somatic ACE using different substrates and inhibitors. Angiotensin-I, artificial substrate Hip-His-Leu, bradykinin and substance$P$ peptide all are hydrolyzed by both active sites $(21,47)$, although angiotensin-I and HipHis-Leu are hydrolyzed faster by the C-domain active site (47). The natural hemoregulatory 
peptide $N$-acetyl-Ser-Asp-Lys-Pro (AcSDKP), a negative regulator of stem cells, is cleaved by both active sites, although the $\mathrm{N}$-domain active site hydrolyzes it $\mathbf{5 0}$ times faster than the Cdomain active site (23). The potency of ACE inhibitors for the $\mathrm{C}$-domain active site is ordered from lisinopril $\rightarrow$ enalapril $\rightarrow$ captopril; whereas, this order is reversed for the $\mathrm{N}$ domain active site (51). The ACE characterization from plasma and homogenized tissues of LEW/N and F344/N rats shows no difference either in specific ACE activity or in the catalytic properties of the enzyme using $\mathrm{C}$ - and $\mathrm{N}$-domain specific substrates and/or inhibitors. Therefore, a Leu-341 to Phe substitution in the primary structure of ACE does not affect a major change in the catalytic properties of the enzyme. However, it could affect soluble ACE's half-life, since we found it associated with a 1.5-fold high soluble ACE level.

The degree of elevation of soluble ACE reported here is consistent with the 2-fold variation in human serum ACE that was linked to a deletion (D)/insertion (I) polymorphism of 287 bp $A l u$ repeat element in intron 16 of human ACE gene (52). In normal subjects, the homozygous deletion genotype $(D D)$ is associated with 2-fold higher soluble ACE; whereas, the heterozygous genotype (ID) is linked to an intermediary level of ACE (52). It is still unknown how this polymorphism could regulate the level of soluble ACE (53). However, this genetic marker is commonly used in association with different diseases, including cardiovascular diseases (54), various autoimmune/ inflammatory pathologies such as systemic lupus erythematosus (55), Alzheimer's disease (56), and sarcoidosis (57). Recently, multiple, naturally occurring mutations and polymorphisms have been reported in the human $A C E$ gene (58), although their function is still unknown.

The level of soluble ACE activity was 1.5fold higher in F344/N than in LEW/N rats in both naive and inflammatory conditions. It is not clear whether this difference could be one of the causes of low exudate volume or is, rather, an unrelated marker. Under our experimental conditions, inhibition of soluble ACE in both plasma and exudate did not potentiate exudation in F344/N rats, arguing against a major contribution of ACE to this phenotype. Other genes may certainly be involved in the regulation of exudate volume in this model and they may also be found in linkage disequilibrium with this mutated form of ACE. Furthermore, the mutated and non-mutated forms of ACE appear to be regulated similarly by inflammation, as carrageenan-induced exudation cause a decrease in the level of soluble ACE activity in plasma and exudate in both LEW/N and F344/N rats. The regulation of soluble ACE during inflammation is, thus, not different in these rats. A decrease in soluble ACE also occurs in the blister fluid in the rat blister model (59) or in the plasma of arthritis patients (34).

Interestingly, the pattern of tissue ACE activity in naive LEW/N and F344/N rats shows a tissue-specific difference of ACE activity in kidney and pituitary from $\mathrm{F} 344 / \mathrm{N}$ rats. No difference in ACE activity is observed in the lung, testis, spleen, brain and liver between two strains. The tissue-specific difference of ACE level might be occurring independent of the mutation in the primary structure of ACE in the F344/N rats. It is worth noting that the ACE activity in the kidney is 5 -fold higher in the F344/N than in LEW/N rat. However, naive LEW/N and F344/N rats are both normotensive (60). Moreover, we found that the pituitary ACE activity in the $\mathrm{F} 344 / \mathrm{N}$ rats was 1.5 -fold lower than the LEW/N rats. Such a difference potentially could affect the stress response, since angiotensin-II can act as a stress hormone (61). Interestingly, F344/N rats exhibit a hyperresponsive hypothalamo-pituitary-adrenal (HPA) axis to various stress stimuli, with high levels of corticosterone, adrenocorticotropin hormone, and corticotropin-releasing hormone; whereas, the LEW/N rats are hyporesponsive (3). More investigations are necessary to understand the functional effects of tissuespecific difference of ACE level in the F344/N rats.

In conclusion, we report here a missense mutation in the primary structure of ACE in F344/N rats associated with a low exudate volume and high soluble ACE level. Although this Leu-341 to Phe substitution in ACE does not affect either the specific activity or the catalytic properties of the enzyme, we cannot rule out the possibility that it could potentially have an effect on the clearance of soluble ACE. Nonetheless, chronic inhibition of soluble ACE in plasma and exudate with an ACE inhibitor lisinopril did not reverse the phenotype of resistance to exudation in F344/N rats. Taken together, these data exclude $A C E$ as a candidate gene involved in resistance to inflammatory exudation in F344/N rats. Further studies will be 
necessary to define the role of soluble ACE and to determine the role of other genes in the resistance to exudation in an air pouch model of carrageenan-induced inflammation.

\section{Acknowledgments}

The authors thank Dr. Philip Gold for his interest and support in this project, Dr. Kenneth E. Bernstein for providing rabbit polyclonal anti-mouse ACE antibody, Dr. Sophie Ligier for helpful discussions and Keith Zuckman for his assistance with sequencing.

\section{References}

1. Wilder RL, Calandra GB, Garvin AJ, Wright KD, Hansen CT. (1982) Strain and sex variation in the susceptibility to streptococcal cell wall-induced polyarthritis in the rat. Arthritis Rheum. 25: 1064-1072.

2. Davis JK, Simecka JW, Williamson JS, et al. (1985) Nonspecific lymphocyte responses in F344 and LEW rats: susceptibility to murine respiratory mycoplasmosis and examination of cellular basis for strain differences. Infect. Immun. 49: 152-158.

3. Sternberg EM, Hill JM, Chrousos GP, et al. (1989a) Inflammatory mediator-induced hypothalamic-pituitary-adrenal axis activation is defective in streptococcal cell wall arthritis-susceptible Lewis rats. Proc. Natl. Acad. Sci. U.S.A. 86: 2374-2378.

4. Sternberg EM, Young WSd, Bernardini R, et al. (1989b) A central nervous system defect in biosynthesis of corticotropin-releasing hormone is associated with susceptibility to streptococcal cell wall-induced arthritis in Lewis rats. Proc. Natl. Acad. Sci. U.S.A. 86: 4771-4775.

5. Misiewicz B, Zelazowska E, Raybourne RB, Cizza G, Sternberg EM. (1996) Inflammatory responses to carrageenan injection in LEW/N and F344/N rats: LEW/N rats show sex- and agedependent changes in inflammatory reactions. Neuroimmunomodulation 3: 93-101.

6. Listwak S, Barrientos RM, Koike G, et al. (1999) Identification of a novel inflammation-protective locus in the Fischer rat. Mamm. Genome 10: 362-365.

7. Remmers EF, Longman RE, Du Y, et al. (1996) A genome scan localizes five non-MHC loci controlling collagen-induced arthritis in rats. Nat. Genet. 14: 82-85.

8. Lorentzen JC, Glaser A, Jacobsson L, et al. (1998) Identification of rat susceptibility loci for adjuvant-oil-induced arthritis. Proc. Natl. Acad. Sci. U.S.A. 95: 6383-6387.

9. Becker KG, Simon RM, Bailey-Wilson JE, et al. (1998) Clustering of non-major histocompatibility complex susceptibility candidate loci in human autoimmune diseases. Proc. Natl. Acad. Sci. U.S.A. 95: 9979-9984.
10. Ehlers MR, Riordan JF. (1989) Angiotensinconverting enzyme: new concepts concerning its biological role. Biochemistry 28: 5311-5318.

11. Skidgel RA, Erdos EG. (1993) in The Renin-Angiotensin System (Nicholls, J. I. S. R. a. M. G., ed) Vol. 1, pp. 10.11-10.10, Gower Medical Publishing, London, New York.

12. Emanueli C, Grady EF, Madeddu P, et al. (1998) Acute ACE inhibition causes plasma extravasation in mice that is mediated by bradykinin and substance P. Hypertension 31: 1299-1304.

13. Damas J, Liegeois JF, Simmons WH. (1996) Potentiation of the pro-inflammatory effects of bradykinin by inhibition of angiotensin-converting enzyme and aminopeptidase $\mathrm{P}$ in rat paws. Naunyn Schmiedebergs Arch. Pharmacol 354: 670-676.

14. Suda H, Yamauchi H, Iso T. (1984) Potentiative effect of angiotensin converting enzyme inhibitor on carrageenan edema in rats and the role of tissue kininogen. J. Pharmacobiodyn. 7: 372-377.

15. Israili ZH, Hall WD. (1992) Cough and angioneurotic edema associated with angiotensinconverting enzyme inhibitor therapy. A review of the literature and pathophysiology [see comments]. Ann. Intern. Med. 117: 234-242.

16. Hubert C, Houot AM, Corvol P, Soubrier F. (1991) Structure of the angiotensin I-converting enzyme gene. Two alternate promoters correspond to evolutionary steps of a duplicated gene. J. Biol. Chem. 266: 15377-15383.

17. Erdos EG. (1990) Angiotensin I converting enzyme and the changes in our concepts through the years. Lewis K. Dahl memorial lecture. Hypertension 16: 363-370.

18. Soubrier F, Alhenc-Gelas F, Hubert C, et al. (1988) Two putative active centers in human angiotensin I-converting enzyme revealed by molecular cloning. Proc. Natl. Acad. Sci. U.S.A. 85: 9386-9390.

19. Bernstein KE, Martin BM, Edwards AS, Bernstein EA. (1989) Mouse angiotensin-converting enzyme is a protein composed of two homologous domains. J. Biol. Chem. 264: 11945-11951.

20. Williams TA, Corvol P, Soubrier F. (1994) Identification of two active site residues in human angiotensin I-converting enzyme. J. Biol. Chem. 269: 29430-29434.

21. Jaspard E, Wei L, Alhenc-Gelas F. (1993) Differences in the properties and enzymatic specificities of the two active sites of angiotensin Iconverting enzyme (kininase II). Studies with bradykinin and other natural peptides. J. Biol. Chem. 268: 9496-9503.

22. Jaspard E, Alhenc-Gelas F. (1995) Catalytic properties of the two active sites of angiotensin I-converting enzyme on the cell surface. Biochem. Biophys. Res. Commun. 211 : 528-534.

23. Rousseau A, Michaud A, Chauvet MT, Lenfant M, Corvol P. (1995) The hemoregulatory peptide $\mathrm{N}$-acetyl-Ser-Asp-Lys-Pro is a natural and specific substrate of the $\mathrm{N}$-terminal active site of human angiotensin-converting enzyme. J. Biol. Chem. 270: 3656-3661. 
24. Deddish PA, Wang LX, Jackman HL, et al. (1996) Single-domain angiotensin I converting enzyme (kininase II): characterization and properties. J. Pharmacol. Exp. Ther. 279: 1582-1589.

25. Deddish PA, Marcic B, Jackman HL, Wang HZ, Skidgel RA, Erdos EG. (1998) N-domainspecific substrate and C-domain inhibitors of angiotensin-converting enzyme: angiotensin(1-7) and keto-ACE. Hypertension 31: 912-917.

26. Dive V, Cotton J, Yiotakis A, et al. (1999) RXP 407, a phosphinic peptide, is a potent inhibitor of angiotensin I converting enzyme able to differentiate between its two active sites. Proc. Natl. Acad. Sci. U.S.A. 96: 4330-4335.

27. Ehlers MR, Fox EA, Strydom DJ, Riordan JF. (1989) Molecular cloning of human testicular angiotensin-converting enzyme: the testis isozyme is identical to the C-terminal half of endothelial angiotensin-converting enzyme. Proc. Natl. Acad. Sci. U.S.A. 86: 7741-7745.

28. Ehlers MR, Chen YN, Riordan JF. (1991) Purification and characterization of recombinant human testis angiotensin-converting enzyme expressed in Chinese hamster ovary cells. Protein Expr. Purif. 2: 1-9.

29. Beldent V, Michaud A, Wei L, Chauvet MT, Corvol P. (1993) Proteolytic release of human angiotensin-converting enzyme. Localization of the cleavage site. J. Biol. Chem. 268: 26428-2643.

30. Beldent V, Michaud A, Bonnefoy C, Chauvet MT, Corvol P. (1995) Cell surface localization of proteolysis of human endothelial angiotensin Iconverting enzyme. Effect of the amino-terminal domain in the solubilization process. J. Biol. Chem. 270: 28962-28969.

31. Oppong SY, Hooper NM. (1993) Characterization of a secretase activity which releases angiotensin-converting enzyme from the membrane. Biochem. J. 292: 597-603.

32. Das M, Hartley JL, Soffers RL. (1977) Serum angiotensin-converting enzyme. Isolation and relationship to the pulmonary enzyme. J. Biol. Chem. 252: 1316-1319.

33. Esther CR, Marino EM, Howard TE, et al. (1997) The critical role of tissue angiotensin-converting enzyme as revealed by gene targeting in mice. J. Clin. Invest. 99: 2375-2385.

34. Sheikh IA, Kaplan AP. (1987) Assessment of kininases in rheumatic diseases and the effect of therapeutic agents. Arthritis Rheum. 30: 138-145.

35. Zubenko GS, Volicer L, Direnfeld LK, Freeman M, Langlais PJ, Nixon RA. (1985) Cerebrospinal fluid levels of angiotensin-converting enzyme in Alzheimer's disease, Parkinson's disease and progressive supranuclear palsy. Brain Res. 328: 215-221.

36. Matucci-Cerinic M, Pignone A, Lotti $\mathrm{T}$, et al. (1990) Reduced angiotensin converting enzyme plasma activity in scleroderma. A marker of endothelial injury? J. Rheumatol. 17: 328-330.

37. Silverstein E, Friedland J, Lyons HA, Gourin A. (1976) Elevation of angiotensin-converting enzyme in granulomatous lymph nodes and serum in sarcoidosis: clinical and possible pathogenic significance. Ann. N.Y. Acad. Sci. 278: 498-513.

38. Friedland J, Setton C, Silverstein E. (1978) In- duction of angiotensin converting enzyme in human monocytes in culture. Biochem. Biophys. Res. Commun. 83: 843-849.

39. Okamura A, Rakugi H, Ohishi M, et al. (1999) Upregulation of renin-angiotensin system during differentiation of monocytes to macrophages. J. Hypertens. 17: 537-545.

40. Costerousse O, Allegrini J, Lopez M, AlhencGelas F. (1993) Angiotensin I-converting enzyme in human circulating mononuclear cells: genetic polymorphism of expression in T-lymphocytes. Biochem. J. 290: 33-40.

41. Caldwell PR, Seegal BC, Hsu KC, Das M, Soffer RL. (1976) Angiotensin-converting enzyme: vascular endothelial localization. Science 191: 1050-1051.

42. Defendini R, Zimmerman EA, Weare JA, Alhenc-Gelas F, Erdos EG. (1983) Angiotensinconverting enzyme in epithelial and neuroepithelial cells. Neuroendocrinology 37: 32-40.

43. Correa FM, Plunkett LM, Saavedra JM. (1986) Quantitative distribution of angiotensinconverting enzyme (kininase II) in discrete areas of the rat brain by autoradiography with computerized microdensitometry. Brain Res. 375: 259-266.

44. Karalis K, Crofford L, Wilder RL, Chrousos GP. (1995) Glucocorticoid and/or glucocorticoid antagonist effects in inflammatory disease-susceptible Lewis rats and inflammatory disease-resistant Fischer rats. Endocrinology 136: 3107-3112.

45. Koike G, Krieger JE, Jacob HJ, Mukoyama M, Pratt RE, Dzau VJ. (1994) Angiotensin converting enzyme and genetic hypertension: cloning of rat cDNAs and characterization of the enzyme. Biochem. Biophys. Res. Commun. 198: 380-386.

46. Langford KG, Zhou Y, Russell LD, Wilcox JN, Bernstein KE. (1993) Regulated expression of testis angiotensin-converting enzyme during spermatogenesis in mice. Biol. Reprod. 48: 12101218.

47. Wei L, Alhenc-Gelas F, Soubrier F, Michaud A, Corvol P, Clauser E. (1991) Expression and characterization of recombinant human angiotensin I-converting enzyme. Evidence for a C-terminal transmembrane anchor and for a proteolytic processing of the secreted recombinant and plasma enzymes. J. Biol. Chem. 266: 5540-5546.

48. Karalis K, Sano H, Redwine J, Listwak S, Wilder RL, Chrousos GP. (1991) Autocrine or paracrine inflammatory actions of corticotropinreleasing hormone in vivo. Science 254: 42 1-423.

49. Sambrook J, Fritsch EF, Maniatis T. (1989) Molecular Cloning, a Laboratory Manual, second edition. Cold Spring Harbor Laboratory Press, Plainview, NY, pp. 5.18.

50. Van der Schueren J, Robben J, Volckaert G. (1998) Misfolding of chloramphenicol acetyltransferase due to carboxy-terminal truncation can be corrected by second-site mutations [In Process Citation]. Protein Eng. 11: 1211-1217.

51. Wei L, Clauser E, Alhenc-Gelas F, Corvol P. (1992) The two homologous domains of human angiotensin I-converting enzyme interact differ- 
ently with competitive inhibitors. J. Biol. Chem. 267: 13398-13405.

52. Rigat B, Hubert C, Alhenc-Gelas F, Cambien F, Corvol P, Soubrier F. (1990) An insertion/ deletion polymorphism in the angiotensin Iconverting enzyme gene accounting for half the variance of serum enzyme levels. J. Clin. Invest. 86: 1343-1346.

53. Rosatto N, Pontremoli R, De Ferrari G, Ravazzolo R. (1999) Intron 16 insertion of the angiotensin converting enzyme gene and transcriptional regulation. Nephrol. Dial. Transplant. 14: 868-871.

54. Staessen JA, Ginocchio G, Wang JG, et al. (1997) Genetic variability in the renin-angiotensin system: prevalence of alleles and genotypes. J. Cardiovasc. Risk 4: 401-422.

55. Sato H, Akai Y, Iwano M, et al. (1998) Association of an insertion polymorphism of angiotensin-converting enzyme gene with the activity of systemic lupus erythematosus. Lupus 7: 530-534.

56. Kehoe PG, Russ C, McIlory S, et al. (1999) Variation in DCP1, encoding ACE, is associated with susceptibility to Alzheimer disease [letter]. Nat. Genet. 21: 71-72.

57. Furuya K, Yamaguchi E, Itoh A, et al. (1996) Deletion polymorphism in the angiotensin I converting enzyme (ACE) gene as a genetic risk factor for sarcoidosis. Thorax 51: 777-780.

58. Rieder MJ, Taylor SL, Clark AG, Nickerson DA. (1999) Sequence variation in the human angiotensin converting enzyme. Nat. Genet. 22: 59-62.

59. Jackson B, White D, Cubela R, Helme R. (1985) Angiotensin converting enzyme and substance $P$ changes in blister fluid following afferent nerve stimulation in the rat. Clin. Exp. Pharmacol. Physiol. 12: 187-191.

60. Tanase H, Yamori Y, Hansen CT, Lovenberg W. (1982) Heart size in inbred strains of rats. Part 1. Genetic determination of the development of cardiovascular enlargement in rats. Hypertension 4: 864-872.

61. Aguilera G, Young WS, Kiss A, Bathia A. (1995) Direct regulation of hypothalamic corticotropinreleasing-hormone neurons by angiotensin II. Neuroendocrinology 61: 437-444. 